Adriana X. Jacobs

Oxford University

\title{
Anna Herman and the Goldberg Variations
}

The capacious first issue of Ho!, a prominent Israeli literary journal that debuted in 2005, included a seven-page questionnaire titled “Variyatsiot Goldberg,” a pun on Bach’s Goldberg Variations, a composition for the harpsichord. The purpose of the questionnaire was-and still is, if you choose to do it—-to answer the question "Are you or are you not Leah Goldberg?”, one of the major modern Hebrew poets of the twentieth century. ${ }^{1}$ The short epigraph that followed this question comprised of two lines from Goldberg's debut collection Smoke Rings (1935): “The clock hands wind around like raised, surprised eyebrows/asking: Are you her? Are you?” The implication being that the question “are you Leah Goldberg?” is one that the poet asked herself. Whether or not you are Goldberg comes down to whether you can answer several biographical questions, but also whether or not you can correctly complete lines from Goldberg's poems. The list of thirty questions concludes with a portrait of Goldberg holding a cigarette, one of many iconic images that featured Goldberg smoking, but this image stands out not only as a nod to the title of her first book, but also because her pose is both an invitation and the final question, as if to say that sharing a smoke with the poet is the final test of identification with the poet (her death from lung cancer not withstanding?). In successfully completing this test, you become one of Goldberg's "variations."

When Goldberg emigrated in 1935 from Germany to Palestine, Smoke Rings was already in print and guaranteed her entree into the moderna, a group of Hebrew Modernists whose affiliations were predominantly with Western European and Russian poetry of the fin-

\footnotetext{
${ }^{1}$ The inspiration for this feature was a questionnaire published on the bicentennial of Victor Hugo's birth (Edouard and Lindon, 2002).
} 
de-siècle and early 20th century. These were relations that Ho!'s first issue revived in its choice of translations (mostly drawn from French and Russian literature) and its penchant for neoformalism and classical prosody (which opened the journal to charges of anachronism). But Goldberg, who was born in Kovno in 1911, was also a writer who fashioned her Israeli identity from many cultural, linguistic, and historical sources, and this prismatic lens also has accorded well with Ho!'s transnational and translational framing of modern Hebrew literature (Manor, 13). Nevertheless, encouraging reader identification with Goldberg, however playful, raises questions concerning Ho!'s investment in Goldberg as a paragon and in the transfer of capital that occurs when her name and texts are cited, appropriated and rewritten —and, not to mention, the value of this capital when anyone, as the questionnaire suggests, can be Leah Goldberg. These questions particularly concern the section of texts that follow the questionnaire, and specifically a contribution by the poet Anna Herman: the sonnet sequence "Yod-daleth sonetot bikavot Leah Goldberg," Fourteen Sonnets after Leah Goldberg, where "after” is indicated by the prepositional phrase "bikavot," literally, on the heels of (Herman, 2005).

In what follows, I will use Herman's poem and its own variations as a case study for an auto-exotic reading of contemporary Hebrew poetry and how it reabsorbs, rewrites and revises its own canon and “sources” toward a comparative and transnational framing of Israeli literature. Herman’s intertextual engagement with and appropriations of Goldberg have been the most extensive of the Ho! poets, but her work, including this text, rejects the patrilineal and hierarchal tropes of legacy and affiliation that persist in modern Hebrew literature and its scholarship. Comparing the sonnet sequence that Herman published in $\mathrm{Ho!}$ with the later version that appeared in her 2006 collection Sefer ha-refuot ha-peshutot (The Book of Simple Remedies), allows me to trace the development of a cannibalistic poetics of relation through Herman's practice of naming, citing and rewriting other (usually, earlier) 
poets - and Goldberg in particular. In her reading of North American poetry of the twentieth century, Rachel Galvin proposes that we understand relations between texts and authors according to a "cannibalistic logic": "instead of seeing the literary canon as a source-a point of origin that engenders progeny, reiterations, borrowings, and references—cultural cannibalism proposes that later texts absorb, devour, or radically re-author earlier works” (Galvin, 18). In contemporary literary studies, the cannibalistic turn to which Galvin refers traces back to Oswaldo de Andrade’s landmark 1928 text "Manifesto antropófago" (Cannibal Manifesto), which proposed a counter-colonial revision of Brazilian literature’s relation to its European precursors (de Andrade, 2002). Invoking the Tupi people, who reportedly ate their enemies to absorb their power and strength, de Andrade and his contemporaries proposed aggressive strategies of textual appropriation and translation that drew from a range of cultures and languages to create-or in their words, transcreate - texts that complicate, recontextualize and multiply their relation to their "precursors.” This discourse is largely absent in the Hebrew context, though a "cannibalistic logic," as well as a poetics of displacement, translation and recycling, pervades the work of modern Hebrew and Israeli poets through the twentieth century to the present day. For example, in her 1973 essay “Words Like Rare Birds,” the Israeli poet Esther Raab (1894-1981) described herself as a gidul pere, a wild vine, in the field of Hebrew poetry, thereby invoking a parasitic, cannibalistic metaphor that rejected traditional models of Hebrew literary affiliation (Raab, 419). In her own work, Raab, who was celebrated as the first "native” modern Hebrew poet, absorbed the languages, styles and forms of Western European poets like Walter Calé, Charles Baudelaire and Germaine Beaumont, but these relations have remained relatively unexplored in studies of her work. ${ }^{2}$ Raab herself used the term "influence” ambivalently,

\footnotetext{
${ }^{2}$ My current book project, Strange Cocktail: Translation and the Making of Modern Hebrew Poetry, discusses these relations at length.
} 
instead remarking, in terms that accord with the cannibalistic mode, "they only nourished me, they didn’t influence me” (Raab, 419).

On the contrary, if we go by the title alone, the reader of Ho! is meant to understand Herman’s poetic sequence as an homage, as an acknowledgment of a Goldberg legacy to which Herman feels her work is affiliated and indebted. Readers familiar with Goldberg's oeuvre also would identify the opening line of this poem- "how they bloomed the lover's

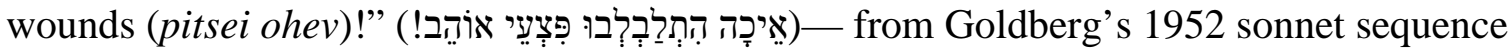
"Pitsei ohev" (The Lover’s Wounds). There, it appears as the closing line of the first sonnet, whereas in Herman's poem, it opens the sequence-yet another indication (it would seem) that Herman's text follows “on the heels of” Goldberg's earlier poem. What the differences between this and the subsequent version reveal, on the contrary, are Herman's strategies for claiming the primary and original status of her own poem through a "radical re-authoring” of Goldberg and other textual "sources.”

Although the term "variation” entails degrees of replication and copying, in the work of the Ho! poets, appropriations of Goldberg's work and biography-through paraphrase, citation, allusion, and rewriting — are fundamentally creative (not to mention that situating a female poet as your paragon is also fundamentally feminist given the male-centeredness of the modern Hebrew canon). But if the desire is, as Ho!'s manifesto insisted, in transformation, revision, and innovation, how can these appropriations be framed and activated in ways that are not hierarchical and linear-that is "on the heels of"-but rather transcreative and relational? Like Glenn Gould’s famed interpretation of Bach’s Goldberg Variations, how can Herman's variation of Goldberg stand on its own?

Returning now to the sequence Herman published in The Book of Simple Remedies, a few notable changes are discernible. The first was the change of title to "Pitsei ohev," The Lover's Wounds, which at first glance appears simply to replicate Goldberg's own title 
(Herman, 2006). The second difference is an addition of an epigraph that confirms

Goldberg's authorship of the line "how they bloomed the lover's wounds." These changes seem to reinforce Herman’s acknowledgment of Goldberg’s influence on her work. In molecular biology, the relation between a cell and the cells that emerge from its division (which carry identical replications of its DNA) is described in genealogical terms: mother cell, daughter cells. The changes made to the second version of Herman's poetic sequencewhere Herman's line represents an identical replication of Goldberg's line-appear to strengthen the genetic affiliation between Herman’s and Goldberg’s poems, but the addition of the epigraph in the 2006 version unsettles these family ties. In the epigraph, the line of “eikha hitlavlevu pitsey ohev!” is a clearly marked and authored citation, appearing, as is customary, in quotation marks and followed by Goldberg's name, making it clear to the reader that these are not Herman's original words. But the line that opens Herman's poem, though lexically identical to Goldberg's line, is copied and inserted into the text without any markers (quotation marks) that would differentiate it from the remaining text or, even more radically, acknowledge their “original” authorship:

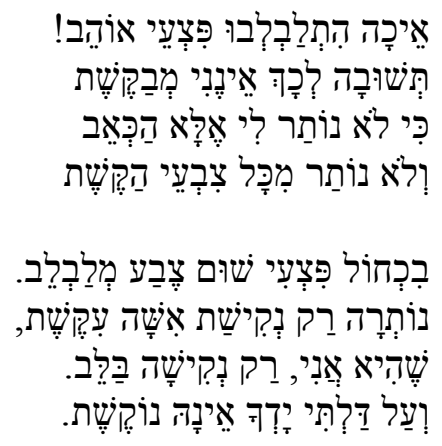

How they bloomed the wounds of love!

I'm not looking for an answer

because nothing remained but the pain

and none of the colors of the rainbow

In the blue of my wound no color blooms.

Only the knocking of a stubborn woman remained, I am she, only a knock on the heart.

And on my door your hand won't knock. (Sonnet 1, lines 1-8) 
Herman's poem can claim its own status because the poet makes it a point at the onset to distinguish between Goldberg's words and her own. The line in the epigraph may belong to Goldberg, but how Herman copies and circulates these words, and the new relations that result in the process, is entirely her labor. In the 2005 version, on the other hand, the title, and particularly the phrase “on the heels of,” assigns a source status to Goldberg’s text (and body). There the reader is meant to read citations and allusions to Goldberg's work within an explicit frame of influence, where Goldberg's poem offers a point of reference for reading and understanding Herman’s text. But by turning Goldberg into an epigraph in the 2006 version, Herman activates a transfer of capital between her poem and Goldberg's while simultaneously initiating a process of recombination that will result in an entirely different, unique sequence.

Cannibalistic appropriations of this kind recur throughout Herman's poem, where one finds images and expressions, even whole lines, from Goldberg’s “original” sequence absorbed to create new contexts. But Herman also copies and recycles her own text, opening a sonnet with the line that closes the one preceding it as well as repeating other lines throughout the sequence (in fact, lines from Herman's poems have a tendency to migrate in this fashion across her two collections). In this respect, Herman explicitly activates an autoexotic mode of self-citation that—by simulating the ways in which she cites Goldbergcomplicates her own authorship. This is also evident in the sixth line of the first sonnet, where the phrase, "I am she” appears in parentheses, which Herman removes in the second version. In so doing, Herman opens her speaker (and herself) to the possibility of being absorbed fully by and into the text to further multiply, transform and recombine.

Additionally, although Herman's poem reproduces the exclamation in Goldberg's line, she also discerns that Goldberg is also posing a question here (“how?”), a question that Herman’s speaker acknowledges but will not resolve: “I’m not looking for an answer,” her 
speaker declares emphatically. Goldberg's poem was later published in the 1955 collection Barak ba-boker (Lighting in the Morning), and is addressed, as many poems in this collection are, to "ha-na'ar," the young man, and specifically to his absence. Herman takes this estranged addressee and reabsorbs him, textually and figuratively, in the poem, where he is embodied parasitically in the line: “ani cholemet she-ata ubar,” I dream that you are an embryo. Herman, like the Israeli poets Yonah Wallach and Dalia Ravikovitch—who are also devoured by this text—consistently deploys maternal metaphors in her work, sometimes in relation to the poetic text itself. But the embryo in Herman's poem is not Goldberg's progeny; rather, this figure represents Herman's appropriation and reimagining of "ha-na ‘ar.” Indeed, Herman rejects Goldberg's tendency to express desire, and specifically female desire, in abstract and figurative terms. In Herman’s poem, the “lover's wounds” bleed and scar; the pain they cause is real, present and material. Outside of the poem, Herman's speaker acknowledges, the lover of Goldberg’s poem “continues to move in a desert of estrangement,” but in Herman’s poem, a strange world begins to stir and come together, made possible by the dream of his recreation.

Hans Christian Anderson’s “The Snow Queen” (Snedronningen) provides the connective tissue of Herman's sequence and of the new context that emerges out of this dream. Those familiar with the story will recall that it introduces the existence of a mirror that reflects back a hideous, deformed and distorted image of the world, the handiwork of an evil, mischievous troll. The mirror won't reflect the good things in the world, but on its surface all terrible things are magnified. One day the mirror shatters and its shards fall to the earth, where they scatter, blowing into eyes and hearts, wreaking havoc with human perspective. In her poem, Herman’s speaker compares herself to Gerda, the young protagonist of Anderson's tale. Gerda, or Greta as she appears in Herman's poem, sets out to find her lost friend Kai, who has fallen under the spell of this trollish mirror. He falls into a 
deep depression when the world turns, in his view, dark, and is vulnerable to the enchantments of the Snow Queen, whose kisses induce amnesia. At the end of the tale, Gerda finds Kai and her tears loosen the shard from his eyes, restoring the beauty of the world to his gaze. In Herman’s reworking of this story, the poem’s addressee is Goldberg herself, transcreated in Herman's poem as the disillusioned Kai, in the 13th stanza of the cycle:

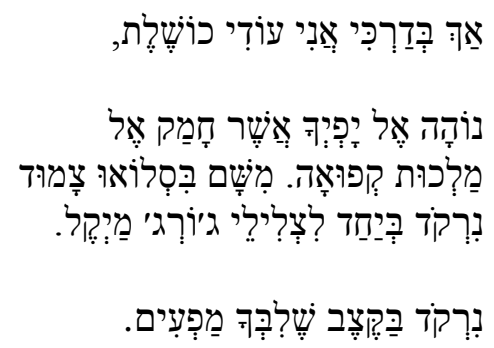

But I still stumble on my path,

longing for your beauty which has slipped into the frozen kingdom. Over there we'll slow dance together to George Michael.

We'll dance to the rhythm of your heartbeat. (Sonnet 13, lines 8-13)

Proverbs 27:6 cautions that "the wounds of a friend (pitsei ohev) are faithful; but the kisses of an enemy are plentiful” (King James Version). In Anderson’s “The Snow Queen,” Gerda’s kiss restores Kai; in Herman's poem, the two bodies come together, dancing to the beat of the lover’s heart (WHAM!'s “Heartbeat”?), an embodiment of the prosodic beat of the sonnet, Goldberg's favored form. It is the beat of a heart coming back to life, "returning to a lost Paradise” and living on in rhyme:

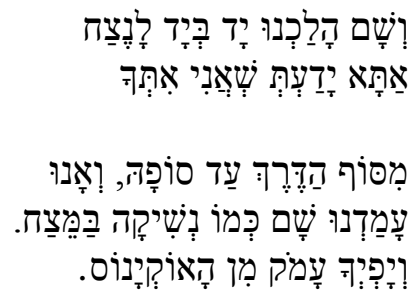

And there we walked hand in hand, always you knew that I was with you 
from end to end, and we stood there like a kiss on the forehead.

And your beauty was deeper than the ocean. (Sonnet 14, lines 10-14)

The phrase "like a kiss on the forehead" returns us to a cannibalistic poetics, to the ravenous kisses the Snow Queen gives Kai, emptying him of memory and filiation. The first kiss numbs the cold; the second erases the memory of friends and family, like the vampiric kisses in an untitled 1917 poem by Marina Tsvetaeva, which closes with the promise "A kiss on the head—erases memory” (Tsvetaeva, trans. Elaine Feinstein, 1994). A third kiss would kill Kai-but the queen holds this one back.

In Herman’s poem, the kiss is a somatic metaphor for the encounter between the lovers, an encounter that happens "sham,” over there. In Herman's “sham” there are crystalline echoes as well of Yona Wallach’s poem "Sham yesh,” There There Are, a quasiEdenic space for unpredictable pairings, not unlike the intertextual encounter between two very different texts, or the ludic and unexpected combinations that hinge on Herman's rhymes. But "there” is also Europe, the other unnamed lover of Goldberg's sequence, which Herman revives as well in this poem. Goldberg's poem "Pitsei ohev" is among many things a lamentation for the distance that separates Goldberg from her European, diasporic home, but it is also an expression that features in a key moment of her 1945 essay "Your Europe." Addressing her beloved Europe of "Dante, Giotto, Michelangelo, Goethe and Flaubert, Mozart, Stendhal, Verlaine, Rilke, Rodin, Cézanne, Stravinsky, James Joyce,” Goldberg also alludes to the aforementioned verse from Proverbs: “We won’t forget you, we won’t forget the wounds of the lover, the wounds of the enemy" (Goldberg, 1945). Redescribing the relation between Herman and Goldberg in terms of cultural and literary cannibalism not only deemphasizes tropes of patrimony and lineage, linearity and continuity, that prevail still in modern Hebrew literary scholarship, but also calls attention to the extensive comparative, transhistoric and multilingual relations that her poem activates_relations that Herman 
transfers back to Goldberg. A third kiss would wipe Goldberg's wounds away, erase them entirely, but instead, Herman's kiss remains in state of suspension-between restoration and death—facing "a beauty deeper than the ocean” that projects the boundless possibility of both texts, and both poets, to connect or disconnect, retreat or approach, consume and digest.

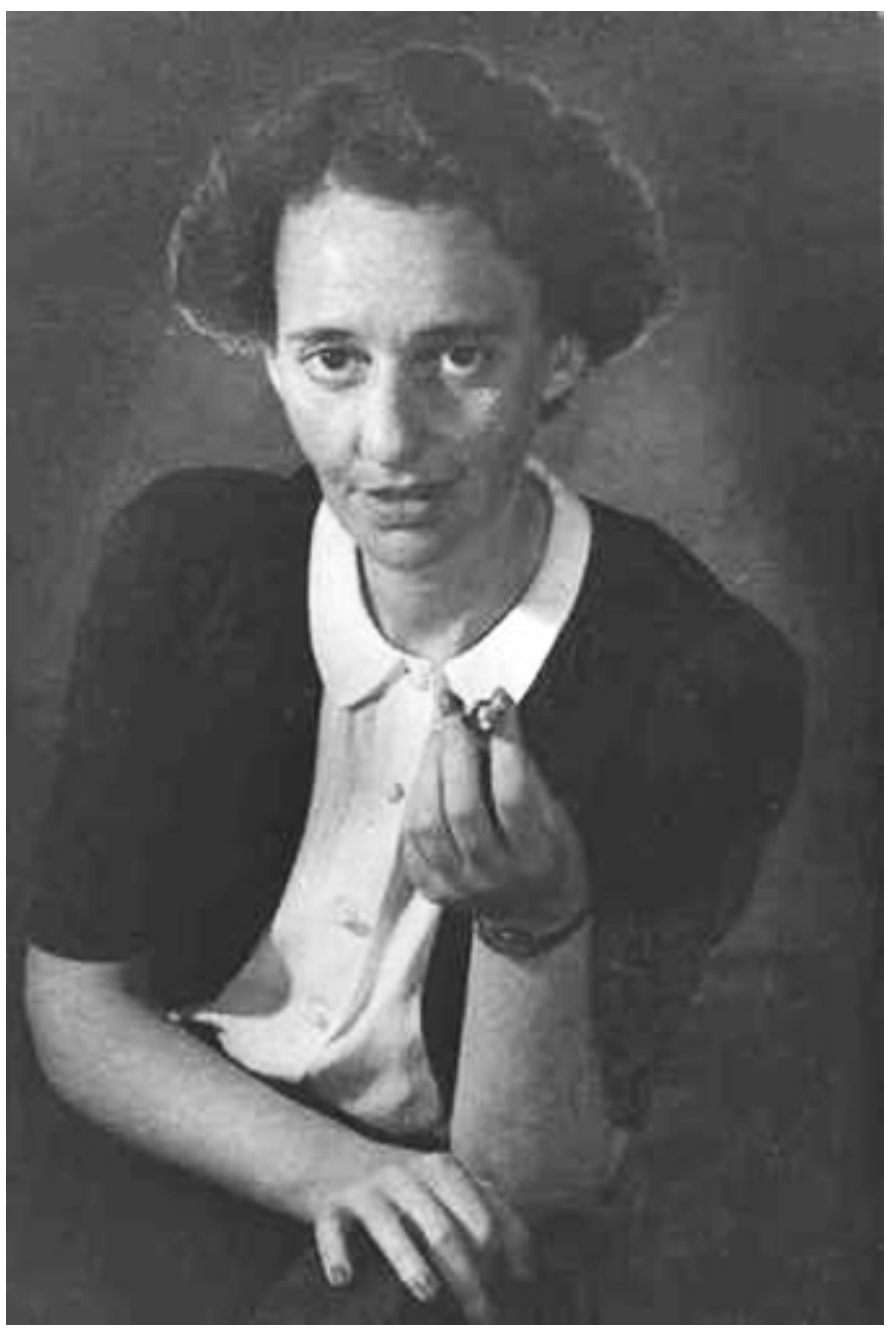

\section{Works Cited}

Launet, Edouard and Mathieu Lindon, “Êtes-vous Victor Hugo?” Libération 3 Jan. 2002. Web.

de Andrade, Oswald. “Manifesto Antropofago.” Revista de Antropofagia 1, 1 (May 1928): 3, 7. Print.

Galvin, Rachel. "Poetry is Theft.” Comparative Literature Studies 51.1 (2014): 18-54. Print. Goldberg, Leah. "Eiropah shelakhem” [Your Europe]. Mishmar. 30 Apr. 1945: 6. Print.

Herman, Anna. "Yod-daleth sonetot bikavot Leah Goldberg," Ho! 1 (2005): 124-130. Print. Herman, Anna. "Pitsei ohev" [The Lover's Wounds]. Sefer ha-refuot ha-peshutot [The Book of Simple Remedies]. Tel Aviv: Ha-kibbuts ha-meuchad, 2006. 14-27. Print.

Manor, Dory. ““Al 'Ho!’” [Ho! Manifesto], Ho! 1 (2005): 9-16. Print.

Raab, Esther. "Milim ke-tsiporim nedirot” [Words Like Rare Birds]. Kol ha-prozah [The 
Collected Prose]. Ed. Ehud Ben-Ezer. Hod Ha-Sharon: Astrolog, 2001. 414-20. Print. Tsvetaeva, Marina. “A kiss on the head.” Trans. Elaine Feinstein. Selected Poems. New York: Penguin Books, 1994. 33. Print. 